\title{
Use of Borax Sludge as an Additive in Wall Tile
}

\author{
Mine Özdemir, İlker Kıpçak \\ Department of Chemical Engineering, Eskişehir Osmangazi University, Eskişehir, Turkey \\ Email:mnozdemi@ogu.edu.tr
}

How to cite this paper: Özdemir, M. and Kıpçak, İ. (2016) Use of Borax Sludge as an Additive in Wall Tile. Journal of Materials Science and Chemical Engineering, 4, 39-45. http://dx.doi.org/10.4236/msce.2016.412005

Received: October 21, 2016

Accepted: December 5, 2016

Published: December 8, 2016

Copyright $(0) 2016$ by authors and

Scientific Research Publishing Inc.

This work is licensed under the Creative

Commons Attribution International

License (CC BY 4.0).

http://creativecommons.org/licenses/by/4.0/

\begin{abstract}
In this research, the use of borax sludge, which is generated in borax industry, as an additive in wall tile, was investigated. The wall tile samples were prepared by adding boron waste to the wall tile composition in the range of $2 \%-10 \%$. The effect of boron waste on the physical and mechanical properties of wall tile was determined. The results obtained were compared with the control tile and Turkish Standards (TS). The boron waste addition up to $8 \mathrm{wt} . \%$ was found to improve the water absorption and strength of wall tile.
\end{abstract}

\section{Keywords}

Boron Sludge, Wall Tile, Water Absorption, Drying Strength, Firing Strength

\section{Introduction}

Turkey has $72 \%$ of the total world boron reserves and is one of the world's largest producers of borates with 2.2 million ton/year. Most boron reserves are in the form of colemanite $\left(2 \mathrm{CaO} \cdot 3 \mathrm{~B}_{2} \mathrm{O}_{3} \cdot 5 \mathrm{H}_{2} \mathrm{O}\right)$ and tincal $\left(\mathrm{Na}_{2} \mathrm{O} \cdot 2 \mathrm{~B}_{2} \mathrm{O}_{3} \cdot 10 \mathrm{H}_{2} \mathrm{O}\right)$ in Turkey. Borates are used in over 100 industries including glass, ceramics, enamels, detergents and insulation fibers [1]. Borax sludge is generated in significant amounts during the beneficiation of boron minerals and the production of boron compounds in Turkey. Annually 400,000 tons of borax wastes are formed in the tincal plants. This waste containing from $8 \%-20 \% \mathrm{~B}_{2} \mathrm{O}_{3}$ is discharged in to the ponds. When these waste ponds overflow, they damage agricultural areas [2]. As boron compounds in this waste pass into soil, they form some complexes with heavy metals so that the potential toxicity of heavy metals increases [3]. Thus, boron compounds cause some serious health and environmental problems when the complexes pass to groundwater. So, there is a need to find the applications of this waste.

The concept of utilization of solid wastes and sludges contains the main principles of recovery, recycling and converting to value added products. Recovery and recycling is a 
well-known process. But, it again produces waste which causes disposal problems [4]. Borax sludge mainly comprises $\mathrm{B}_{2} \mathrm{O}_{3}, \mathrm{CaO}, \mathrm{MgO}, \mathrm{Na}_{2} \mathrm{O}$ and $\mathrm{SiO}_{2}$. Therefore, recently, there have been some studies on the use of boron wastes in the production of cement [5] [6] [7]. It is also an attractive candidate for making ceramic bodies such as wall tile and floor tile. Boron compounds are known to be a good fluxe in ceramics. These compounds form a glassy structure by bonding with silica and alkalis. They also reduce the melting temperature, increase thermal expansion coefficient and lead to a very tough body [8]. The possibility of using clay tailings from a borax concentrator in red brick production was investigated and up to $30 \%$ by weight tailings addition was found to improve the brick quality [9]. The effect of heat treatment on colemanite for the production of borides as related the ceramic industry was elucidated. The results showed that the raw colemanite could be processed through calcination in temperature range of $400^{\circ} \mathrm{C}-600^{\circ} \mathrm{C}$ [10]. The effect of coal fly ash and borax waste on the properties of wall tile was investigated. The firing strength of wall tile increased when the fly ash and borax waste used in the preparation of the standard tile composition was determined [11]. Although some studies on the use of boron wastes for ceramic production have been carried out, there does not exist any study on the use of borax sludge. For that reason, the aim of this study was to investigate the use of borax sludge as an additive in wall tile. The boron waste was characterized with respect to its chemical composition and mineral phases in the study. The wall tile samples were produced by adding boron waste to wall tile mixture at various ratios. The physical and mechanical properties of wall tiles were discussed in this text.

\section{Material and Methods}

\subsection{Material}

The borax sludge used in this study was provided from Etibank Kurka Borax Plant in Eskişehir, Turkey. The solid and liquid parts of this sludge were separated by filtering. The solid part was dried at room temperature and then sieved by using ASTM standard sieves. The particles smaller than 100 mesh were used in the experiments. The chemical analysis of boron waste was carried out by using XRF ARL 8680. The chemical analysis for boron oxide content was achieved by volumetric method [12]. The chemical composition of boron waste is given in Table 1 . Boron waste was characterized by X-ray diffraction (XRD). XRD was performed in Philips PW 1830 equipment. The wall tile mixture was taken from the outlet of spray dryer in Altın Ceramics Plant, Kütahya, Turkey. The chemical composition of the tile mixture is presented in Table 1 . The mineral composition of this mixture consisted of $41.87 \%$ kaolin, $24.03 \%$ quartz, $22 \%$ feldspar and $12 \%$ other additives.

\subsection{Methods}

Before the wall tile samples were prepared, the moisture contents of boron waste and the wall tile mixture were determined. According to this, the weight of wall tile mixture was adjusted to $2500 \mathrm{~g}$ and boron waste ratios in the wall tile samples were $0 \%, 2 \%, 4 \%$, 
Table 1. Chemical compositions of boron waste and wall tile mixture.

\begin{tabular}{ccc}
\hline Component $(\%, w / w)$ & Boron waste & Wall tile mixture \\
\hline $\mathrm{SiO}_{2}$ & 9.82 & 57.78 \\
$\mathrm{Al}_{2} \mathrm{O}_{3}$ & 1.30 & 19.15 \\
$\mathrm{Fe}_{2} \mathrm{O}_{3}$ & 1.49 & 1.53 \\
$\mathrm{TiO}_{2}$ & - & 0.33 \\
$\mathrm{CaO}$ & 16.85 & 3.81 \\
$\mathrm{MgO}$ & 13.01 & 3.12 \\
$\mathrm{Na}_{2} \mathrm{O}$ & 10.30 & 1.12 \\
$\mathrm{~K}_{2} \mathrm{O}$ & 1.01 & 2.12 \\
$\mathrm{~B}_{2} \mathrm{O}_{3}$ & 19.44 & - \\
$\mathrm{SO}_{3}$ & - & 0.08 \\
Loss of ignition & 26.78 & 10.96 \\
\hline
\end{tabular}

$6 \%, 8 \%$ and $10 \%$, by weight. The wall tile sample without boron waste was designed as control tile. After $0.9 \% \mathrm{Na}_{2} \mathrm{SiO}_{2}$ and $50 \%$ water were added to these samples, they were ground and mixed in a ball ceramic mill of $5 \mathrm{~L}$ capacity in the range of $50-60 \mathrm{rpm}$ for $15 \mathrm{~min}$. These mud samples were passed through a $150 \mu \mathrm{m}$ sieve and then were completely dried in an oven at $105^{\circ} \mathrm{C} \pm 5^{\circ} \mathrm{C}$. The dried samples were ground in an agate mortar. The obtained powder was humidified at $6 \%$ humidity ratio and then was molded in $100 \mathrm{~mm} \times 80 \mathrm{~mm} \times 6 \mathrm{~mm}$ molds by pressing at $15 \mathrm{~N} / \mathrm{mm}^{2}$. The samples prepared in this way were dried in an oven at $80^{\circ} \mathrm{C}$ for $12 \mathrm{~h}$ and then were fired in a roller furnace at $1130^{\circ} \mathrm{C}$ for $35 \mathrm{~min}$. The tests of drying shrinkage, firing shrinkage, weight loss, bulk density, water absorption, drying strength and firing strength were applied to samples according to TS EN ISO 10,545 [13].

\section{Results and Discussion}

\subsection{Characterization of Boron Waste}

The chemical analysis and XRD of the boron waste are given in Table 1 and Figure 1, respectively. The major component of the boron waste is $\mathrm{B}_{2} \mathrm{O}_{3}$ and a significant alkaline oxide content $\left(\mathrm{CaO}+\mathrm{MgO}+\mathrm{Na}_{2} \mathrm{O}\right)$ is also present. XRD of the boron waste shows that it consists of dolomite $\left[\mathrm{CaMg}\left(\mathrm{CO}_{3}\right)_{2}\right]$, searlesite $\left[\mathrm{NaBSi}_{2} \mathrm{O}_{5}(\mathrm{OH})_{2}\right]$, calcite $\left(\mathrm{CaCO}_{3}\right)$ and smectite $\left[(\mathrm{OH})_{4} \mathrm{Si}_{8} \mathrm{Al}_{4} \mathrm{O}_{20} \mathrm{nH}_{2} \mathrm{O}\right]$. Thus, these analyses indicate that boron waste is adequate for usage in the ceramics.

\subsection{Production of Tiles}

Five types of wall tile samples were prepared with boron waste at various ratios, and one control tile without boron waste. The drying shrinkage, firing shrinkage, weight loss, bulk density, water absorption, drying strength and firing strength values of these samples were determined. The results obtained are given in Table 2, Figure 2 and Figure 3. 
Table 2. Shrinkage, weight loss, bulk density, water absorption and strength of wall tile samples.

\begin{tabular}{|c|c|c|c|c|c|c|c|}
\hline $\begin{array}{c}\text { Boron waste ratio } \\
(\%, w / w)\end{array}$ & $\begin{array}{c}\text { Drying shrinkage } \\
(\%)\end{array}$ & $\begin{array}{c}\text { Firing shrinkage } \\
(\%)\end{array}$ & $\begin{array}{l}\text { Weight loss } \\
(\%)\end{array}$ & $\begin{array}{l}\text { Bulk density } \\
\left(\mathrm{g} / \mathrm{cm}^{3}\right)\end{array}$ & $\begin{array}{c}\text { Water absorption } \\
(\%)\end{array}$ & $\begin{array}{l}\text { Drying strength } \\
\qquad\left(\mathrm{N} / \mathrm{mm}^{2}\right)\end{array}$ & $\begin{array}{l}\text { Firing strength } \\
\left(\mathrm{N} / \mathrm{mm}^{2}\right)\end{array}$ \\
\hline 0 & 0.29 & 1.10 & 10.14 & 1.82 & 17.40 & 2.89 & 13.69 \\
\hline 4 & 0.66 & 1.20 & 10.87 & 1.83 & 14.97 & 3.24 & 13.87 \\
\hline 10 & 0.59 & 2.12 & 11.64 & 1.77 & 16.15 & 3.72 & 15.87 \\
\hline TS 202 & - & - & - & $\min .1 .70$ & $\max .20 .00$ & - & $\min .15 .00$ \\
\hline
\end{tabular}

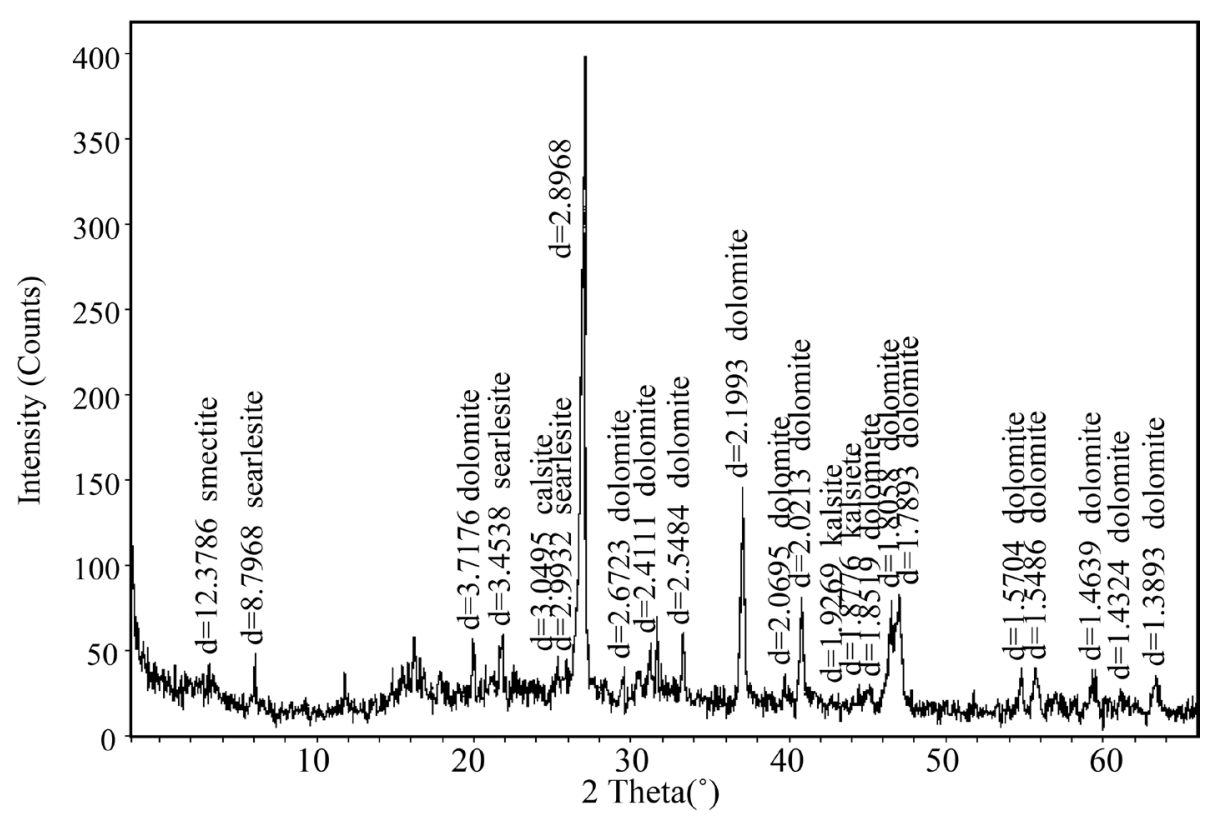

Figure 1. XRD of boron waste.

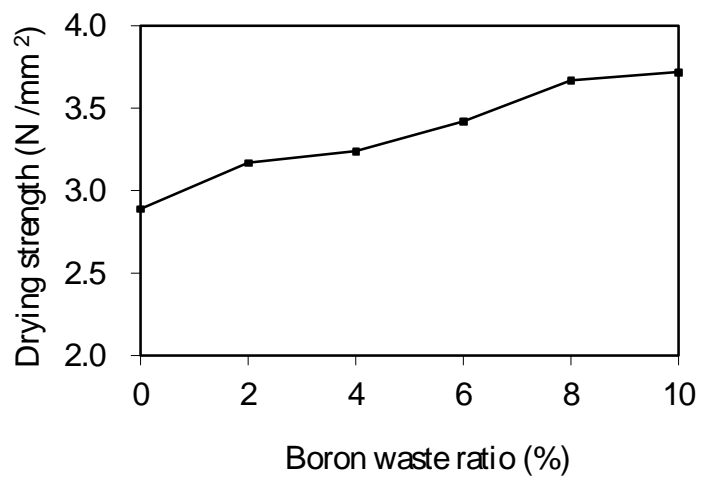

Figure 2. Effect of boron waste ratio on drying strength.

As seen in Table 2, drying and firing shrinkages generally increase with increasing boron waste ratio. While drying shrinkage and firing shrinkage of the control tile are 


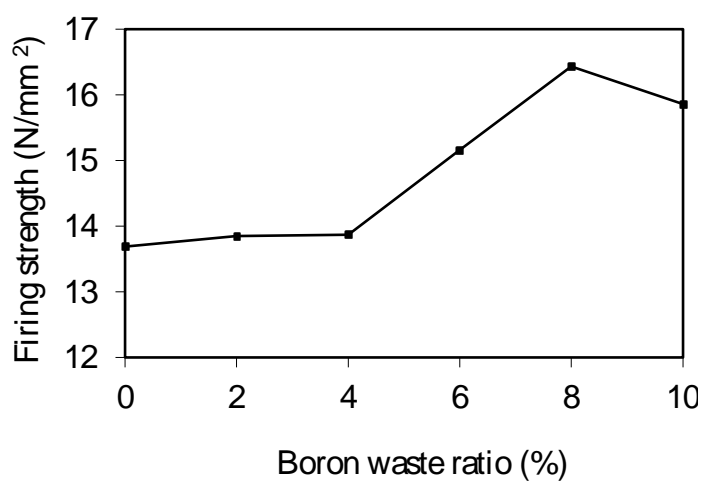

Figure 3. Effect of boron waste ratio on firing strength.

$0.29 \%$ and $1.10 \%$, respectively, those of the wall tile with $10 \%$ boron waste addition are $0.59 \%$ and $2.12 \%$, respectively. The increase in drying shrinkage is due to the clay amount of tile body which increases with the clay content of boron waste used in the production of tile. The release of mechanical water and hydroscopic water from the clay and kaolin during drying causes that particles in the body come closer and closer together until they touch, leading to shrinkage [14]. It was observed that boron waste melted at $720^{\circ} \mathrm{C}$. This result can be explained by the fact that the high $\mathrm{B}_{2} \mathrm{O}_{3}, \mathrm{MgO}, \mathrm{CaO}$ and $\mathrm{Na}_{2} \mathrm{O}$ contents in boron waste behave as network former, network co-formers and network modifiers, respectively, for the formation of glassy phase and lower the melting temperature of glassy phase [8]. So, the addition of boron waste increases the values of firing shrinkage.

The wall tile including boron waste has a bigger loss of weight by firing and a bigger firing shrinkage depending on how much more boron waste is contained in the tile (Table 2). The weight loss results from the dehydration and the evolution of carbon dioxide coming from the decomposition of dolomite and calcite. Bulk density changes between 1.77 and $1.88 \mathrm{~g} / \mathrm{cm}^{3}$ and is higher than the minimum value of $1.7 \mathrm{~g} / \mathrm{cm}^{3}$ according to TS 202 [15]. Higher bulk density is obtained due to the increasing of shrinkage and the reducing of porosity during sintering. The results of water absorption tests also confirm this situation. The water absorption values of the wall tiles including boron waste are lower than that of control tile (Table 2). This result indicates that glassy mass fills in the pores and thus lowers water absorption. In addition, the water absorption values are less than the maximum of $20 \%$ in TS 202 [15].

The drying strength results are shown in Figure 2. The drying strength of wall tile including $10 \%$ boron waste is $3.72 \mathrm{~N} / \mathrm{mm}^{2}$ while drying strength of the control tile is $2.89 \mathrm{~N} / \mathrm{mm}^{2}$. Thus, in the case of using boron waste in wall tile production, there is an increase of about $29 \%$ in the drying strength in comparison with the control tile. This results in the increase in the ratio of the clay mineral used as binder in the tile body.

As seen in Figure 3, while boron waste ratio increases from $0 \%$ to $8 \%$, the firing strength of the tile increases from $13.69 \mathrm{~N} / \mathrm{mm}^{2}$ to $15.86 \mathrm{~N} / \mathrm{mm}^{2}$. This can be explained by the fact that the fluxes such as $\mathrm{B}_{2} \mathrm{O}_{3}, \mathrm{MgO}, \mathrm{CaO}$ and $\mathrm{Na}_{2} \mathrm{O}$ cause a significant increase in the sintering of body by decreasing the porosity of tile body and thereby leading to a 
denser body. When boron waste over $8 \%$ was added to wall tile, there is a decrease in the firing strength of wall tile. The reason of this may be that a large extent of fluxing oxides forms a glassy phase in the excessive amounts [14]. However, the firing strengths of wall tiles including $6 \%, 8 \%$ and $10 \%$ boron waste met the minimum $15 \mathrm{~N} / \mathrm{mm}^{2}$ required by TS 202 [15].

\section{Conclusions}

Borax sludge was tested to determine whether this material can be used as an additive in wall tile production or not. The following results were obtained:

1) The use of boron waste in the control wall tile composition increases the drying shrinkage and the firing shrinkage.

2) The wall tile including boron waste has a bigger loss of weight by firing.

3) The water absorption of tile decreases as the boron waste content of the wall tile is increased.

4) The drying strength and firing strength of the tiles containing boron waste are higher than those of the control tile.

5) The addition of boron waste up to $8 \%$ improved the wall tile quality with respect to water absorption, drying strength and firing strength without compromising the other properties.

6) Boron waste coming from the borax industry may be used as an additive for wall tile production to the extent of a maximum $8 \mathrm{wt} . \%$. By this way, economic loss and the soil and underground water pollution sourced from the borax sludge can be prevented. The production cost of tile can be reduced due to the saving material by the use of boron waste. In addition, energy saving is provided since the boron waste in powder form requires less grinding.

\section{Acknowledgements}

We thank Eskişehir Osmangazi University Research Foundation (Project No. 2000/6) for financial support, Etibank Kırka Borax Plant for borax sludge and Altın Ceramics Plant for laboratory facility.

\section{References}

[1] http://etimaden.gov.tr/

[2] The State Planning Organization (2001) Report No. DPT: 2608. Ankara.

[3] Soiler, H.G., Sigiel, H. and Sigiel, A. (1988) Handbook of Toxicity of Inorganic Compounds. Marcel Dekker, New York.

[4] Das, S.K., Kumar, S. and Ramachandrarao, P. (2000) Exploitation of Iron Ore Tailing for the Development of Ceramic Tiles. Waste Management, 20, 725-729.

https://doi.org/10.1016/S0956-053X(00)00034-9

[5] Boncukçuoğlu, R., Yılmaz, M.T., Kocakerim, M.M. and Tosunoğlu, V. (2002) Utilization of Trommel Sieve Waste as an Additive in Portland Cement Production. Cement and Concrete Research, 32, 35-39. https://doi.org/10.1016/S0008-8846(01)00625-1

[6] Kula, İ., Olgun, A., Sevinç, V. and Erdoğan, Y. (2002) An Investigation on the Use of Tincal 
Ore Waste, Fly Ash, and Coal Bottom Ash as Portland Cement Replacement Materials. Cement and Concrete Research, 32, 227-232.

https://doi.org/10.1016/S0008-8846(01)00661-5

[7] Özdemir, M. and Öztürk, N.U. (2003) Utilization of Clay Wastes Containing Boron as Cement Additives. Cement and Concrete Research, 33, 1659-1661. https://doi.org/10.1016/S0008-8846(03)00138-8

[8] Singer, F. and Singer, S.S. (1963) Industrial Ceramics. Chapman and Hall Ltd., London. https://doi.org/10.1007/978-94-017-5257-2

[9] Uslu T. and Arol, A.I. (2004) Use of Boron Waste as an Additive in Red Bricks. Waste Management, 24, 217-220. https://doi.org/10.1016/S0956-053X(03)00031-X

[10] Yıldız, Ö. (2004) The Effect of Heat Treatment on Colemanite Processing: A Ceramics Application. Powder Technology, 142, 7-12. https://doi.org/10.1016/j.powtec.2004.03.006

[11] Olgun, A., Erdoğan, Y., Ayhan, Y. and Zeybek, B. (2005) Development of Ceramic Tiles from Coal Fly Ash and Tincal Ore Waste. Ceramics International, 31, 153-158. https://doi.org/10.1016/j.ceramint.2004.04.007

[12] Gülensoy, H. (1984) Principles of Complexometry and Complexometric Titrations. Fatih Press, Istanbul.

[13] Turkish Standards Institute (2000) Ceramic Tiles. TS EN ISO 10545, Ankara.

[14] Barsoum, M.W. (1997) Fundamentals of Ceramics. Mc Graw-Hill Comp., New York.

[15] Turkish Standards Institute (2004) Ceramic Tiles-Anatolian Tiles. TS 202, Ankara.

\section{Submit or recommend next manuscript to SCIRP and we will provide best service} for you:

Accepting pre-submission inquiries through Email, Facebook, LinkedIn, Twitter, etc. A wide selection of journals (inclusive of 9 subjects, more than 200 journals)

Providing 24-hour high-quality service

User-friendly online submission system

Fair and swift peer-review system

Efficient typesetting and proofreading procedure

Display of the result of downloads and visits, as well as the number of cited articles

Maximum dissemination of your research work

Submit your manuscript at: http://papersubmission.scirp.org/

Or contact msce@scirp.org 